\section{Bør alle slutte å bruke psykofarmaka?}

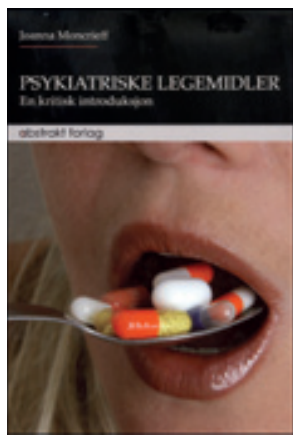

\author{
Joanna Moncrieff \\ Psykiatriske legemidler \\ En kritisk introduksjon. 177 s, tab, ill. \\ Oslo: Abstrakt forlag, 2011. Pris NOK 225 \\ ISBN 978-82-7935-310-2
}

Forfatteren imøtegår det hun oppfatter som en feilaktig forestilling om at psykofarmaka kan reversere en underliggende medisinsk sykdom. Denne sykdomssentrerte modellen erstatter hun med en medikamentsentrert modell som sier at psykofarmaka er psykoaktive stoffer som påvirker nervesystemet og gir rusopplevelse, en intoksikasjon (doseavhengig) på linje med alkohol, cannabis, kokain og heroin. Ifølge modellen erstatter medikamentet en opprinnelig tilstand preget av psykiatriske symptomer med en medikamentindusert tilstand som er unormal for kroppen. Det fører til en biologisk stresstilstand fordi kroppen forsøker å motvirke effektene av den fremmede substansen. Hun medgir at psykofarmaka noen ganger kan være nyttige, men mener generelt at de brukes for ofte, $i$ for store doser og for lenge om gangen.

På omslaget står det at forfatteren er Senior Lecturer i psykiatri ved University College London og praktiserende psykiater. Hun er en av grunnleggerne og lederne i «Critical Psychiatry Network», en gruppe psykiatere som er kritiske til biologisk psykiatri. Hun har publisert flere artikler i velrenommerte tidsskrifter om psykofarmaka. I boken er det kapitler om antipsykotika, antidepressiver, litium og andre stemningsstabiliserende midler, sentralstimulerende midler og benzodiazepiner. Hun er kritisk til mye av forskningen på dette feltet. Randomiserte kontrollerte forsøk mener hun er problematiske fordi metoden er tilpasset somatiske tilstander, som hun mener ikke er hensiktsmessige i psykiatrien. Det er jeg uenig i. Derimot er jeg enig med henne i at langtidseffekter av medisiner generelt er for dårlig kartlagt. Gjennomgående er redegjørelsen preget av lange og gjentakende beskrivelser av alle bivirkninger og med nedtoning av nyttige effekter. Hun mener at alle de omtalte medikamentene generelt har en dempende og beroligende effekt, og at det er det som kan oppfattes som virksomt. Benzodiazepinene får «snillest» omtale fordi de etter forfatterens mening gir mindre bivirkninger enn andre psykofarmaka.

Dette er ikke en bok som gir alternativer til medikamentell behandling. Under behandling av mani nevner forfatteren at foruten beroligende legemidler kan livsstilstiltak være nyttige, f.eks. å unngå stress og ta fri fra arbeid. Ellers nevner hun at ulike former for korttidspsykoterapi bør være tilgjengelige for mennesker med psykiske lidelser. Disse tiltakene er ikke nærmere omtalt, og det er alt som står om alternativene. Boken er oversatt av Kari Marie Thorbjørnsen. Den er lettlest, og oversetteren har gjort et bra arbeid. Det er imidlertid en del unødvendige gjentakelser som forsterker den ensidige fremstillingen. Referansene er valgt for å støtte opp under forfatterens syn. På omslaget står det at alle som bruker eller vurderer å bruke et psykiatrisk legemiddel, og de som forskriver slike midler, burde lese boken. Jeg synes den er for ensidig polemisk til at man kan anbefale den til pasienter og pårørende. Imidlertid kan boken representere et nyttig innspill for leger som administrerer psykofarmaka, slik at disse midlene i størst mulig grad gis etter grundig vurdering, til rett person, i rett dose og i et hensiktsmessig tidsrom. Det forutsetter kunnskaper ut over det du får her, god allianse og tid til oppfølging. Selv om synspunktet druknes litt av alle motforestillingene, står det tydelig, selv her, at mange pasienter har nytte av psykofarmaka.

\section{Stein Opjordsmoen Ilner}

Avdeling for forskning og utvikling

Klinikk psykisk helse og avhengighet

Oslo universitetssykehus, Ullevål

\section{Kommunikasjon for bedre kvalitet i helsetjenesten}

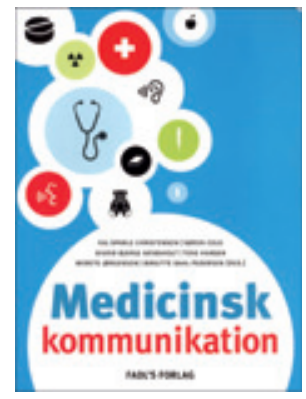

Kaj Sparle Christensen, Søren Cold, Sigrid Bjerge Gribsholt et al, red.

Medicinsk kommunikation

215 s, tab, ill. København: FADL's Forlag,

2011. Pris DKK 330

ISBN 978-87-7749-581-6

Mange klager på helsetjenesten handler om svikt i kommunikasjonen mellom lege og pasient eller mellom aktørene internt i systemet. Dette skyldes både individuelle og strukturelle forhold, manglende kunnskaper og ferdigheter. Kommunikasjon er derfor en like viktig basis for kvalitet og et godt resultat som anatomi, fysiologi og kliniske fag.

I Danmark har man tatt denne utfordringen ved at lærere fra universitetene i København, Århus, Odense og Ålborg har skrevet denne læreboken som pensum for medisinstudenter. Seks redaktører og 12 andre forfattere står bak et imponerende koordinerende arbeid som har resultert i en oversiktlig lærebok, hvor de tar opp de viktigste temaene i 16 oversiktlige kapitler, uten uhensiktsmessig overlapping. De fleste forfatterne er klinikere og universitetslærere, flest fra allmennmedisin. Innholdet bærer preg av at de har bred erfaring, og de setter kommunikasjonen inn i en helhetlig biopsykososial ramme som også omfatter det etiske.

Lege-pasient-forholdet og kommunikasjon blir belyst med eksempler fra ulike situasjoner og tilnærminger: den første samtalen, journal, den motiverende samtalen, den vanskelige, eksistensielle samtalen, den interkulturelle samtalen, samtale med barn i forskjellige aldre, pasienter i krise, sorg og sinne og vold. Også kommunikasjon med kolleger og annet helsepersonell, etikk og profesjonalisme er beskrevet. Fremstillingen preges av en oversiktlig integrering av teori og praktisk ferdighet. Forfatterne legger vekt på at ferdighetene er det viktigste: hva man kan, bør og ikke bør si og gjøre. Det gis også rom for dilemmaene. Boken blir på denne måten både en lærebok i kommunikasjon og i pasientforståelse og behandling. Som kliniker nikker man gjenkjennende.

Kommunikasjon er kunnskap og ferdigheter man må lære, tilpasset ulike pasienter og situasjoner, verbalt og nonverbalt. Tilbakemelding og supervisjon er beskrevet i eget kapittel, og omfatter bruk av video. Mange temaer egner seg i etterutdanning for klinikere, ikke bare for allmennpraktikere.

Forfatterne avslutter hvert kapittel med sammendrag og litteratur. Innholdsfortegnelse og stikkordregister gjør det lett å finne frem. Boken er relativt kompakt, men med to spalter og «bokser» som inneholder bl.a. kasuistikker og ulike kliniske situasjoner, blir den leseverdig. Boken er dansk, og enkelte lover og regler avviker litt fra våre, men det viktigste er greit for norske lesere. Jeg håper likevel at det vil komme en norsk utgave.

Medisinsk kommunikasjon er langt bredere og viktigere enn et spesialisert fag, og ikke bare for medisinstudenter. Det er kunnskap og ferdigheter som vi må holde ved like som klinikere, lærere og veiledere. Kommunikasjon er sammen med kunnskap, kompetanse og kontinuitet kjernen i kvalitet.

Tidligere redaktør Ole K. Harlem (1917-2003) i Tidsskrift for Den norske legeforening drøftet kommunikasjon på bred basis i sin bok allerede i 1977 (1). Utfordringen er ikke blitt mindre. Medisinsk kommunikasjon er et stort fag, det er spesialistoverskridende og med økende betydning for vår virksomhet. Det kan derfor være en oppgave for Tidsskriftet å sette søkelyset på kommunikasjon som det limet og den oljen som får de forskjellige delene av helsetjenesten til å fungere eller ikke. 